Article

\title{
The Assessment of Morphological Diversity of Colchicum luteum L., an Economically Important Threatened Medicinal Plant of Kashmir Himalaya
}

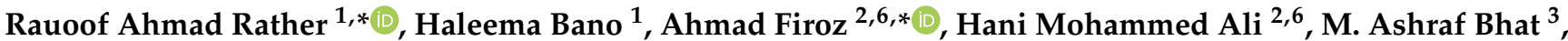 \\ Shahid Ahmad Padder ${ }^{4}$, Huda Nafees ${ }^{5}$ and Khalid Rehman Hakeem $2,6,7, * \mathbb{D}$
}

check for

updates

Citation: Rather, R.A.; Bano, H.; Firoz, A.; Mohammed Ali, H.; Bhat, M.A.; Padder, S.A.; Nafees, H.; Hakeem, K.R. The Assessment of Morphological Diversity of Colchicum luteum L., an Economically Important Threatened Medicinal Plant of Kashmir Himalaya. Sustainability 2022, 14, 1327. https://doi.org/ $10.3390 /$ su14031327

Academic Editor: Marco Manzone

Received: 20 December 2021

Accepted: 17 January 2022

Published: 25 January 2022

Publisher's Note: MDPI stays neutral with regard to jurisdictional claims in published maps and institutional affiliations.

Copyright: (C) 2022 by the authors. Licensee MDPI, Basel, Switzerland. This article is an open access article distributed under the terms and conditions of the Creative Commons Attribution (CC BY) license (https:// creativecommons.org/licenses/by/ $4.0 /)$.
1 Division of Environmental Sciences, Sher-e-Kashmir University of Agricultural Sciences and Technology, Srinagar 190025, Jammu \& Kashmir, India; haleemabano679@gmail.com

2 Department of Biological Sciences, Faculty of Science, King Abdulaziz University, Jeddah 21589, Saudi Arabia; hmohammedali@kau.edu.sa

3 Division of Genetics and Plant Breeding, Faculty of Agriculture, Sher-e-Kashmir University of Agricultural Sciences and Technology, Wadura, Kashmir 193201, Jammu \& Kashmir, India; mashrafbhat@skuastkashmir.ac.in

4 Division of Basic Sciences \& Humanities, Sher-e-Kashmir University of Agricultural Sciences and Technology, Srinagar 190025, Jammu \& Kashmir, India; shahidpadder@skuastkashmir.ac.in

5 Department of Saidla, Aligarh Muslim University, Aligarh 21589, Uttar Pradesh, India; dr.hudanafees@gmail.com

6 Princess Dr. Najla Bint Saud Al-Saud Center for Excellence Research in Biotechnology, King Abdulaziz University, Jeddah 21589, Saudi Arabia

7 Department of Public Health, Daffodil International University, Dhaka 1341, Bangladesh

* Correspondence: rouf.haq@gmail.com (R.A.R.); ahmadfirozbin@gmail.com (A.F.); kur.hakeem@gmail.com (K.R.H.)

Abstract: Colchicum luteum L. is an economically important and endangered medicinal plant of the Kashmir Himalaya. The corm extract is used for the treatment of rheumatism, gout, Behcet's syndrome, and Alzheimer disease. It is also used extensively in plant breeding programs for the doubling of chromosomes. The present study was carried out for two years (2017-2019) to study the genetic diversity of C. luteum, an economically important and endangered medicinal plant of Kashmir Himalaya. The mapping of genetic diversity of $C$. luteum was estimated using Mahalanobis $D^{2}$ analysis in the Aharbal (Kulgam), Dhara (Theed), and Baera Baal Hills (Harwan) of Kashmir Valley. The results showed the presence of 5 clusters for 30 populations. There were 17 populations in cluster-1, 1 in cluster-2, 2 in cluster-3, 3 in cluster- 4 , and 7 in cluster-5. The majority of the population was a group in cluster- 1 followed by cluster-5. The maximum intracluster distance ( $\mathrm{D}^{2}$ values) was observed in cluster-5 (46.55588) followed by cluster-3 (41.61871), and the maximum inter-cluster distance ( $\mathrm{D}^{2}$ values) was observed in cluster-3 (46.55588) followed by cluster-5 (41.61871). Our study revealed that plant species possessed sufficient genetic diversity among the populations. Cluster- 5 showed superiority in plant ${ }^{-1}$ respect of the maximum mean plant height $(28.46 \mathrm{~cm})$, leaf area $\left(47.0 \mathrm{~cm}^{2}\right)$, number of seeds plant ${ }^{-1}(26.85)$, corm length $(5.15 \mathrm{~cm})$, corm width $(3.17 \mathrm{~cm})$, fresh weight of corm plant $(6.87 \mathrm{~g})$, and dry weight of corm plant $(4.81 \mathrm{~g})$ as compared to other clusters. Out of five clusters, cluster-5 is a promising one for better yield and yield attributing traits. The present study revealed that plant species possessed sufficient genetic diversity among the populations as 30 populations were arranged into 5 clusters. Therefore, cluster- 5 , consisting of seven populations from the undisturbed area of Harwan, and consequently the populations from the same cluster can be multiplied for initiating a conservation and breeding program and can serve as a tool for the scientific community to evolve better contemporary varieties of $C$. luteum with profitable characters such as more yield of corms, etc. This will assist farmers, particularly the marginal farmers, to alleviate their income.

Keywords: Colchicum luteum; genetic diversity; cluster distance; $\mathrm{D}^{2}$ analysis; medicinal plant; endangered plants 


\section{Introduction}

The use of medicinal herbs by humans to cure different ailments is time immemorial. These herbs have large curative significance and use as medium and equitable sources for a better and healthy life [1-5]. Medicinal plants are an invaluable source of new drugs and their overexploitation for commercial application is decreasing their density and natural diversity in the wild [6-9]. Eighty per cent of individuals in poor nations rely entirely on herbal remedies for their primary health and more than 25 per cent of recommended products are sourced from wild species in developing countries [6]. There are about 50,000 to 80,000 floral plant species used in therapeutic applications according to the International Union for the Conservation of Nature and World Wildlife Fund statistics on medicinal plants in the world. Due to overharvesting and habitat loss, some 15,000 species are on the verge of disappearing. With rising global population and crop consumption, $20 \%$ of their natural resources have been previously wiped out [10-12]. Though this threat is not new, the rate of species loss and habitat destruction is increased several folds worldwide. It is moving toward the risk of extinction of medicinal plants, especially in India and China along with some African nations [6,13-16]. The Department of Ecology, Environment and Remote Sensing, Jammu and Kashmir, reported that the species C. luteum comes under rare and threatened status [17]. The State Forestry Department believes that during the previous 2 decades, these plants have been massively extracted and smuggled from the Kashmir woods, resulting in their diminished wildlife levels. Colchicum luteum L., commonly known as Suranjan-e-Talkh (Urdu), comes under the family Liliaceae [18]. There are around 280 genera and 4000 species in the Liliaceae family, which are primarily perennial plants with starchy rhizomes, corms, or bulbs. Colchicum species are split into two groups based on the flowering period. Their leaves and flowers occur in distant seasons. C.luetum is a 'monocot plant' and is collected in quantity from the Kashmir meadows. It has tuberous roots which are oval in shape and brown in colour. The leaves are 6-12 inches in length and round in shape with small flowers. The flowers are 1-2 inches in length and around half an inch in width. The blossoming season begins between the middle of February and April and the seeds are matured between April and June. The flowers are hermaphrodite, having female and male organs, and are bee and fly pollinated. It is ideal for low-loam soils and loves well-drained soils which do not grow in shade [19]. These herbal species are commonly present on the edges of the forest or in open grasslands and temperate western Himalayas, from Kashmir to Chamba, at altitudes ranging from 700 to $2800 \mathrm{~m}$ in India. It extends into the other Indian states of Punjab, Himachal Pradesh, and Sikkim, and neighboring countries such as Nepal, Afghanistan, Pakistan, and the Hindu Kush Mountains. In general, it thrives well where climate conditions are low and have a temperature less than $15^{\circ} \mathrm{C}$. Its natural habitat conditions are highlighted by physiologically temperate conditions such as snow, severe winter, as well as lower humidity using corms, which may also be obtained by snow melting in April and May, from natural environments. The plant corms must not be damaged or infected [20-24].

Colchicine is the main alkaloid recovered from all Colchicum species [25]. There are 31 kinds of tropane alkaloids identified from C. luteum [25-27]. Colchicine is a common compound and is renowned for its antimitotic and its hereditary inflammatory disease such as acute gout and family-based Mediterranean fever. [28,29]. The earliest use of colchicine as mitotic inhibitors and for induction of polyploids is reported in 1937 [30,31] and is still popular today in various plant breeding programs [31-33]. It is also used for the treatment of Behcet's syndrome [34,35] and Alzheimer disease [36]. It is also reported that crude ethanolic extracts and different fractions showed lower activity (29-61\%) against acetylcholinesterase and no activity against urease $[37,38]$. The derivatives of colchicine such as demecolcine are used against myeloid leukemia [39] and allocolchinoid phosphatederivative ZD6126 is tested in cancer therapy [40]. Despite all its uses, a cost-effective and productive in vitro synthesis method of Colchicum alkaloids is far from reality and the corms of Colchicum are the source of colchicine extraction. C. luteum species are taxonomically very challenging to class, especially autumn flowering species [41]. The species is facing various 
biotic stresses such as uncontrolled grazing and habitat loss due to various anthropogenic activities such as illegal harvesting, deforestation, construction of roads, and tourism.

Keeping in view the rare and threatened status and enormous medicinal potential of C.luteum, there is no available report on the genetic diversity of the species in Kashmir Himalaya. The success of a conservation program of a species depends on different parameters, including genetic diversity. Therefore, it is the need of the hour to study the genetic diversity of this threatened plant species. The present study was conducted by a comparative analysis of the morphological features of vegetative and reproductive parts of C. luteum. It helps in ascertaining the genetic diversity of C. luteum in Kashmir Himalaya.

\section{Material and Methods}

The study on estimation of the genetic diversity of C. luteum was conducted for two years (2017-2019) at Division of Environmental Sciences, SKUAST-K, Shalimar, J\&K. In Kashmir Himalaya, three areas, namely Aharbal (Kulgam), Dhara (Theed), and Baera Baal Hills (Harwan) (Figure 1), were selected for an exclusive survey of C. luteum population. The data were recorded on ten competitive plant populations from each sub-location and mean values were calculated from three sub-locations in each location. The following morphological characters of the vegetative and reproductive stages were calculated to differentiate the variation in a population.

(a) Plant height $(\mathrm{cm})$ : The plant height was drawn first from the bottom to the tip of the leaf, using a measuring scale, of all populations from selected plants. (b) Leaf area plant $^{-1}\left(\mathrm{~cm}^{2}\right)$ : The area of the leaf was recorded by using the graph method. An outline of a leaf on the graph paper was drawn and a number of squares were calculated. (c) Leaf length $(\mathrm{cm})$ : The length of the leaf was determined from the point of emergence of leaf to the apex of the leaf with the help of scale from the selected plants in all the populations. (d) Leaf width $(\mathrm{cm})$ : The leaf width was measured horizontally from the center of the leaf using a scale on selected plants from all populations. (e) Number of seeds plant ${ }^{-1}$ : The number of seeds from each plant was counted at the time of harvesting from the selected plants in all the populations. (f) Corm length $(\mathrm{cm})$ : The corm length was recorded by using a scale from the selected plants in all the populations. (g) Corm width $(\mathrm{cm})$ : The width of the corm was measured with the help of measuring tape from the selected plants in all the populations. (Corm width $(\mathrm{cm})=\mathrm{X} / 2$ ). (h) Fresh weight of corm $(\mathrm{g})$ : "The fresh weight of the corm per plant was taken separately for each plant by the help of electronic weighing balance'. (i) Dry weight of corm (g): The dry weight of the corm per plant was taken after oven it completely for $24 \mathrm{~h}$, with the help of an electronic weighing balance from the selected plants in all the populations. 


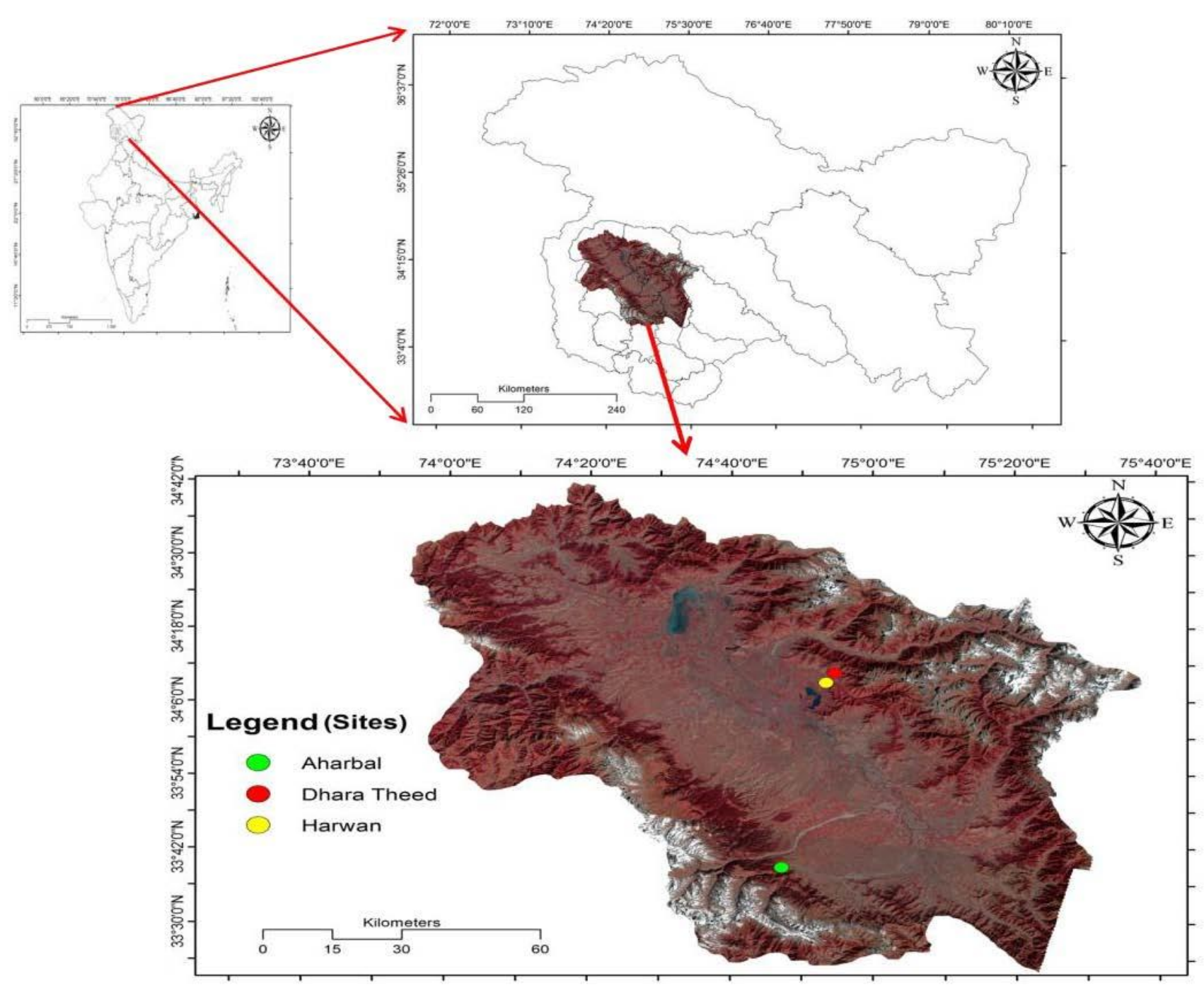

Figure 1. Location map of the selected study areas in Kashmir, Himalaya, viz. Aharbal, Dhara Theed, and Harwan.

\section{Statistical Analysis}

$\mathrm{D}^{2}$ statistics were used to determine the competitive representative diversity of plant populations (Mahalanobis, 1936). Mahalanobis $\mathrm{D}^{2}$ analysis evaluated the data. Computation of $\mathrm{D}^{2}$ values.

The differences in transformed values for various characters were computed and $\mathrm{D}^{2}$-values were calculated according to the following formula:

$$
\mathrm{D}^{2}=\sum_{\mathrm{i}-1}^{\mathrm{p}}\left(\mathrm{Y}_{\mathrm{ij}}-\mathrm{Y}_{\mathrm{ik}}\right)^{2}
$$

where

$\mathrm{P}=$ number of characters studied, and

$\mathrm{Y}_{\mathrm{ij}}$ and $\mathrm{Y}_{\mathrm{ik}}=$ are two transformed variables of the ith character for two genotypes.

All the morphological characters were analyzed for the thirty populations of C. luteum. Using the $\mathrm{D}^{2}$ was adopted between every feasible combination and was calculated. The populations were categorized into different clusters and intra- and intercluster distances were calculated. The data were analyzed and Mahalanobis $\mathrm{D}^{2}$ analysis was performed by using Torcher's method as suggested by Rao [42]. 


\section{Results and Discussion}

In the present study, variability and diversity ( $\mathrm{D}^{2}$ statistic) at the phenotypic level were estimated at three locations (Aharbal-Kulgam, Dhara Theed, Baera Bal Harwan) of Kashmir Valley in thirty populations of C. lutuem (Figure 2). Dendrogram depicting relationship among 30 populations of Colchicum luteum with total of Five clusters showed in Figure 3. Data were recorded on nine phenotypic traits, viz. plant height, leaf area, leaf length, leaf width, number of seeds plant ${ }^{-1}$, corm length, corm width, fresh weight of corm, and dry weight of corms. Genetic diversity was estimated from the data pooled over years using Mahalanobis' $\mathrm{D}^{2}$-statistic which indicated the presence of sufficient genetic diversity among the populations. $\mathrm{D}^{2}$-statistics revealed a total of 5 clusters (Figure 1 and Table 1 ) with 17 populations in cluster-1, 1 (cluster-2), 2 (cluster-3), 3 (cluster-4), and 7 (cluster-5). The majority of populations was grouped in cluster-1, followed by cluster-5 (Table 1). According to Rao [43], no formal rules can be laid down for forming a cluster, yet any two genotypes belonging to the same cluster should at least, on average, show a smaller $\mathrm{D}^{2}$ value as compared to two genotypes falling into many clusters. Work from Ahmad and Borah [44] observed that the clustering pattern reflected considerable influence on genetic diversity. There is no similarity between genetic diversity and geographic location, the contributions of different genotypes in many different clusters at times. In this study (Phaseolus volgaris L.), the genetic diversity of 36 six genotypes were also evaluated for 13 yields and yield attributive properties and grouped into six clusters via Mahalanobis. The largest cluster-1 was followed by cluster- 6 and cluster- 2 and -3 with 19 different genotyping types. The genetic divergence of sesame (Sesamum indicum L) in 2019, a set of 96 advancing breeding lines of genotype, was classified in 15 clusters, as per Table 1 and Figure 1, by Hukumchand and Parameshwarappa [45]. Cluster-I was the highest of the 68 line clusters, cluster-2 (11), cluster-5 (4), and cluster-11, respectively.

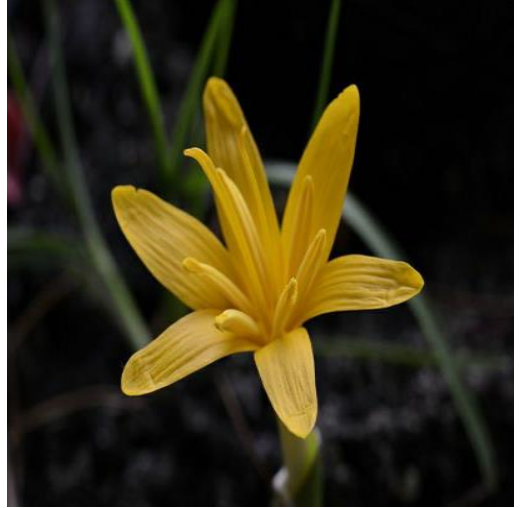

(a)

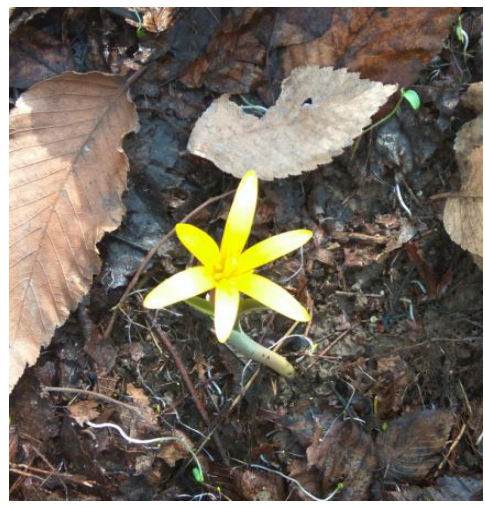

(b)

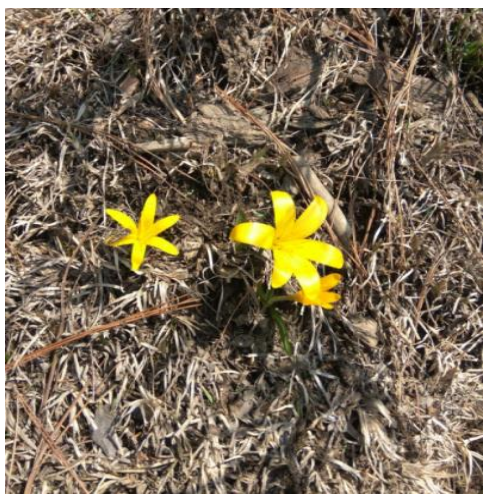

(c)

Figure 2. Images of C. luteum during flowering stage from the three locations, (a) Harwan, (b) Dhara Theed, and (c) Aharbal, showing morphological variations from undisturbed to disturbed sites of Kashmir Himalaya. 


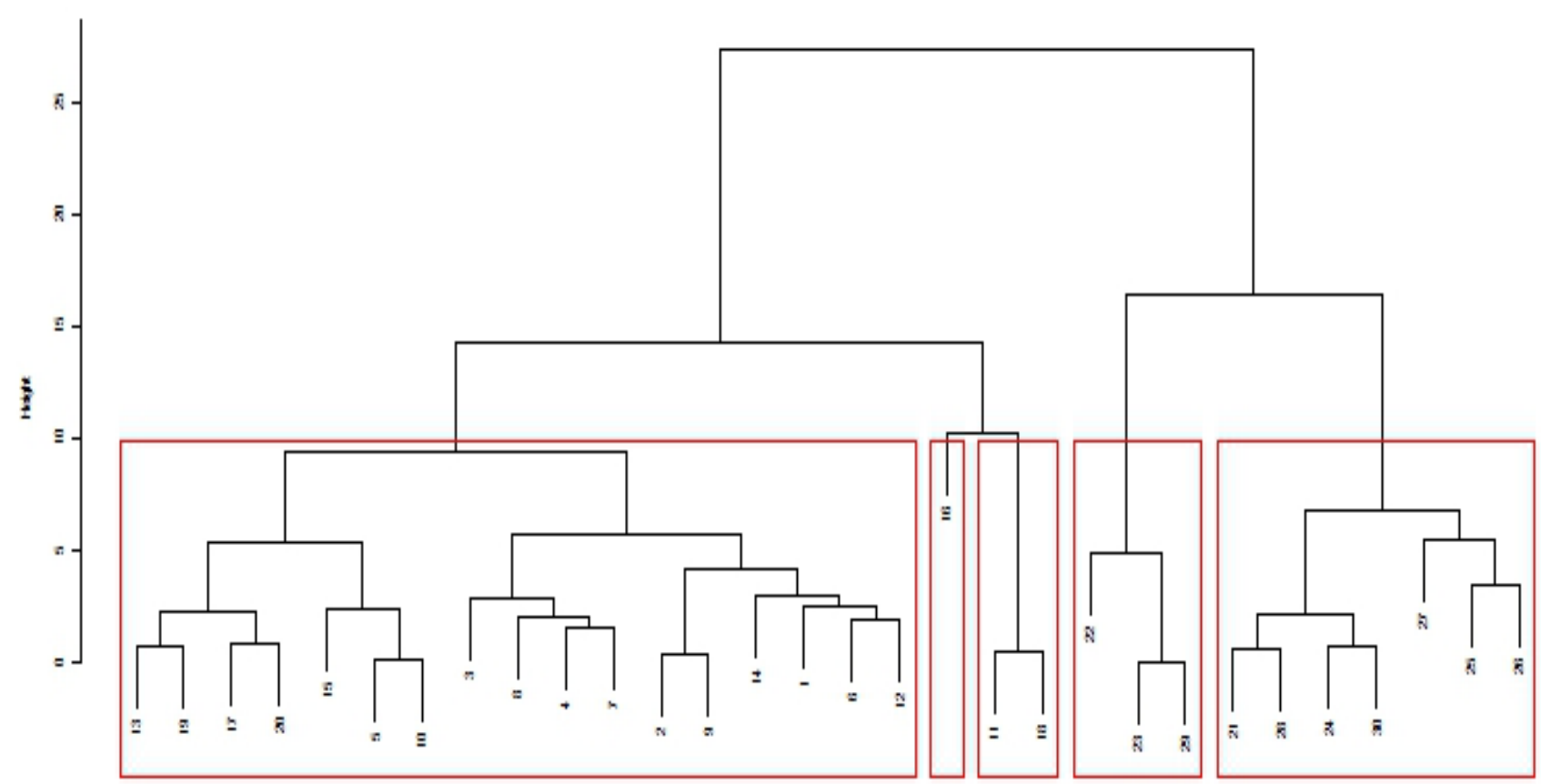

Figure 3. Dendrogram depicting genetic relationship amongst 30 populations of Colchicum luteum of forest hills of Kashmir Himalaya.

Table 1. Classification of Colchicum luteum populations of forest hills of Kashmir Himalaya into different clusters on the basis of the genetic diversity.

\begin{tabular}{ccc}
\hline Cluster No. & Number of Populations/Landraces & Name of the Population/Landrace \\
\hline Cluster-1 & 17 & P1, P2, P3, P4, P5, P6, P7, P8, P9, P10, P12, P13, P14, P15, P17, P19, P20 \\
\hline Cluster-2 & 1 & P16 \\
\hline Cluster-3 & 2 & P11, P18 \\
\hline Cluster-4 & 3 & P22, P23, P29 \\
\hline Cluster-5 & 7 & P21, P24, P25, P26, P27, P28, P30 \\
\hline
\end{tabular}

The mean performance of the traits in a cluster and different phenotypes falling within a cluster are presented in Table 2 . The maximum mean plant height $(28.46 \mathrm{~cm})$ was recorded in cluster-5, followed by cluster-4 $(27.71 \mathrm{~cm})$, and the lowest plant height mean was found in cluster-3 (13.0). The maximum mean leaf area $(47.0 \mathrm{~cm})$ was recorded in cluster-5, followed by cluster-4, while the minimum leaf area was found in cluster-1 $(28.79 \mathrm{~cm})$. The maximum mean leaf length $(19.51 \mathrm{~cm})$ was recorded in cluster-5, followed by cluster-4, and the minimum leaf length $(11.6 \mathrm{~cm})$ was found in cluster-1. The maximum leaf width $(1.32 \mathrm{~cm})$ was recorded in cluster-5, followed by cluster- 4 , while the minimum leaf width (0.97) was found in cluster-1. The maximum number of seeds (26.85) was recorded in cluster-5, followed by cluster-4, while the minimum number of seeds (11.41) was found in cluster-1. The maximum corm length $(5.15 \mathrm{~cm})$ was recorded in cluster-5, followed by cluster-4, while the minimum corm length (3.06) was found in cluster-2. The maximum corm width plant $(3.17 \mathrm{~cm})$ was recorded in cluster-5, followed by cluster-4, while minimum corm width (2.05) was in cluster-1. The maximum fresh weight of the corm plant (6.87 g) was recorded in cluster-5, followed by cluster-4, while the minimum fresh weight of corm $(2.27 \mathrm{~g})$ was found in cluster-1. The maximum dry weight of the corm plant ( $4.81 \mathrm{~g}$ ) was in cluster-5, followed by cluster-4, while minimum dry weight of corm $(1.58 \mathrm{~g})$ was found in cluster- 1 (Table 2). The descriptive statistics for the parameters considered in the study are given in Table 3. 
Table 2. Cluster mean performance of morphological, yield and yield component traits of populations of C. luteum of forest hills of Kashmir Himalaya.

\begin{tabular}{|c|c|c|c|c|c|c|c|c|c|}
\hline $\begin{array}{c}\text { Cluster } \\
\text { No. }\end{array}$ & $\begin{array}{l}\text { Plant } \\
\text { Height } \\
\text { Plant }^{-1} \\
\text { (cm) }\end{array}$ & $\begin{array}{c}\text { Leaf Area } \\
\text { Plant }^{-1} \\
\text { (Sq.cm) }\end{array}$ & $\begin{array}{c}\text { Leaf } \\
\text { Length } \\
\text { Plant }^{-1} \\
\text { (cm) }\end{array}$ & $\begin{array}{c}\text { Leaf } \\
\text { Width }(\mathrm{cm}) \\
\text { Plant }^{-1}\end{array}$ & $\begin{array}{l}\text { No. of } \\
\text { Seeds } \\
\text { Plant }^{-1}\end{array}$ & $\begin{array}{l}\text { Corm } \\
\text { Length } \\
\text { Plant }^{-1} \\
(\mathrm{~cm})\end{array}$ & $\begin{array}{l}\text { Corm } \\
\text { Width } \\
\text { Plant }^{-1} \\
\text { (cm) }\end{array}$ & $\begin{array}{c}\text { Fresh } \\
\text { Weight of } \\
\text { Corm } \\
\text { Plant }^{-1} \text { (g) }\end{array}$ & $\begin{array}{c}\text { Dry } \\
\text { Weight of } \\
\text { Corm } \\
\text { Plant }^{-1} \text { (g) }\end{array}$ \\
\hline 1 & $14.32^{\mathrm{d}}$ & 28.79 e1 & $11.66^{\mathrm{e} 2}$ & $0.97^{\mathrm{e} 3}$ & $11.41^{\mathrm{e} 4}$ & $3.08^{\text {e5 }}$ & $2.05^{\mathrm{e} 6}$ & $2.27^{\mathrm{e} 7}$ & $1.58^{\mathrm{ed}}$ \\
\hline 2 & $19.20^{c}$ & $35.52^{d 1}$ & $15.31^{D^{2}}$ & $1.16^{\mathrm{d} 3}$ & $12.02^{\mathrm{d} 4}$ & $3.06^{\mathrm{d} 5}$ & $2.07^{\mathrm{d} 6}$ & $3.82^{\mathrm{c} 7}$ & $2.21^{\mathrm{c} 8}$ \\
\hline 3 & $13.01^{\mathrm{e}}$ & $36.03^{c 1}$ & $12.18^{\mathrm{c} 2}$ & $1.15^{c 3}$ & $24.03^{c 4}$ & $3.50^{c 5}$ & $2.40^{c 6}$ & $2.55^{d 7}$ & $1.62^{\mathrm{d} 8}$ \\
\hline 4 & $27.71^{b}$ & $44.50^{\mathrm{b} 1}$ & $15.54^{\mathrm{b} 2}$ & $1.20^{\mathrm{b} 3}$ & $24.05^{\mathrm{b} 4}$ & $4.30^{\mathrm{b} 5}$ & $2.63^{b 6}$ & $5.37^{b 7}$ & $2.94^{\mathrm{b} 8}$ \\
\hline 5 & $28.46^{\mathrm{a}}$ & $47.01^{\mathrm{a} 1}$ & $19.51^{\mathrm{a} 2}$ & $1.32^{\mathrm{a} 3}$ & $26.85^{a 4}$ & $5.15^{a 5}$ & $3.17^{a 6}$ & $6.87^{a 7}$ & $4.81^{\mathrm{a} 8}$ \\
\hline
\end{tabular}

Subscripts indicate that within the column the values with same letters did not differ y Tukey's test.

Table 3. The descriptive statistics for the 30 populations of Colchicum luteum.

\begin{tabular}{ccccc}
\hline & Minimum & Maximum & Mean & Std. Deviation \\
\hline Plant height & 10.21 & 35.30 & 19.8771 & 7.99874 \\
\hline Leaf area & 22.50 & 54.50 & 34.7786 & 9.08518 \\
\hline Leaf length & 8.44 & 20.10 & 13.9062 & 3.46952 \\
\hline Leaf width & 0.68 & 5.25 & 1.2232 & 0.80632 \\
\hline No. of seeds & 7.00 & 28.00 & 15.6786 & 6.63355 \\
\hline Corm length & 1.50 & 5.17 & 3.6034 & 0.95686 \\
\hline Corm width & 1.10 & 3.24 & 2.3239 & 0.59166 \\
\hline Fresh weight of corm & 1.10 & 8.45 & 3.7155 & 1.95302 \\
\hline Dry weight of corm & 0.67 & 6.32 & 2.3348 & 1.38865 \\
\hline
\end{tabular}

The maximum cluster mean of different phenotypic traits comprises of plant height, leaf area, leaf length, leaf width, number of seeds ${ }^{-1}$, corm length, corm width, fresh weight of corm, and dry weight of corm, and were predominately found at undisturbed areas recorded in cluster-5 and cluster- 4 , and the lowest values were found at disturbed areas recorded in cluster-3, cluster-2, and cluster 1 (Table 2). In accordance with other crops, work performed by Hukumchand and Parameshwarappa [45] on Sesamum indicum L.), in which they assessed the traits seed yield per plant $(42.43 \%), 1000$ seed weight $(18.44 \%)$, number of capsules per plant (9.25), and height to the first capsule (6.82), have contributed the maximum to genetic divergence. In addition, [46] worked on (Phaseolus vulgaris L.), in which they studied the traits green pod yield contributed diversity $(40.17 \%)$ followed by plant height (18.89 per cent). The highest green pod yield was $165 \mathrm{~g}$ per plant, while it recorded an average number of pods (23.85). Increasingly, the possibilities of heterotic expression in F1 and broad variation across segregating progeny are seen to be the more diversified parents within their fitness overall bounds [47-52]. The cluster pattern might be utilized to choose parents for the hybridization procedure to give the greatest potential diversity to various economic characteristics [53-55]. Furthermore, this should work to interconnect genotypes across a wide range of variabilities and to construct transgressive segregates for C, such as cluster (I and V), clusters (I and V), and clusters (I and IV). In addition, the cluster value performance of 30 populations of $C$. luteum at different locations of Kashmir is validated in the DMRT (Table 4). 
Table 4. DMRT test validate the cluster value performance of 30 populations of Colchicum luteum.

\begin{tabular}{|c|c|c|c|c|c|c|c|c|c|}
\hline $\begin{array}{c}\text { Populations } \\
\text { Characters/Codes }\end{array}$ & $\begin{array}{l}\text { Plant } \\
\text { Height }\end{array}$ & Leaf Area & $\begin{array}{c}\text { Leaf } \\
\text { Length }\end{array}$ & $\begin{array}{l}\text { Leaf } \\
\text { Width }\end{array}$ & $\begin{array}{l}\text { No. of } \\
\text { Seeds }\end{array}$ & $\begin{array}{l}\text { Corm } \\
\text { Length }\end{array}$ & $\begin{array}{l}\text { Corm } \\
\text { Width }\end{array}$ & $\begin{array}{c}\text { Fresh } \\
\text { Weight } \\
\text { of Corm }\end{array}$ & $\begin{array}{c}\text { Dry } \\
\text { Weight } \\
\text { of Corm }\end{array}$ \\
\hline $\mathrm{P}(1)$ & $11.35^{\mathrm{jkl}}$ & 24.25 op & $9.15^{n}$ & $0.71^{b}$ & 8.00 ef & $2.62 \mathrm{~m}$ & $1.43^{b c}$ & $1.08^{f}$ & $0.79 \mathrm{~lm}$ \\
\hline $\mathrm{P}(2)$ & $10.70^{\mathrm{kl}}$ & $23.00 \mathrm{pq}$ & $8.35^{\circ}$ & $0.70^{\mathrm{b}}$ & 8.00 ef & $1.77^{\circ}$ & $1.11^{\mathrm{c}}$ & $1.72 \mathrm{ef}$ & $1.16^{\mathrm{kl}}$ \\
\hline $\mathrm{P}(3)$ & $14.00^{\mathrm{hi}}$ & $28.50^{\mathrm{jk}}$ & $11.60^{\mathrm{ij}}$ & $0.97^{b}$ & $11.00 \mathrm{def}$ & 3.21 ghij & $2.05 \mathrm{abc}$ & 2.43 def & $1.43^{\text {hijk }}$ \\
\hline $\mathrm{P}(4)$ & $12.40 \mathrm{ijk}$ & $26.50^{\mathrm{lmn}}$ & $10.70^{\mathrm{k}}$ & $0.89^{b}$ & $10.00 \mathrm{def}$ & $3.20_{\text {hijk }}$ & $1.93 \mathrm{abc}$ & $2.16^{\text {def }}$ & $1.09 \mathrm{klm}$ \\
\hline $\mathrm{P}(5)$ & 16.40 efg & $29.05^{j}$ & $11.95^{\mathrm{i}}$ & $1.10^{\mathrm{b}}$ & $14.00^{\mathrm{d}}$ & $3.42 \mathrm{fg}$ & $2.01 \mathrm{abc}$ & $3.36^{\text {cde }}$ & $2.04^{\mathrm{fg}}$ \\
\hline $\mathrm{P}(6)$ & $12.35^{\mathrm{ijkl}}$ & $24.50^{\circ p}$ & $9.83^{m}$ & $0.81^{\mathrm{b}}$ & 12.00 def & $2.46^{\mathrm{m}}$ & $3.03^{\mathrm{ab}}$ & $1.10^{\mathrm{f}}$ & $0.67 \mathrm{~m}$ \\
\hline $\mathrm{P}(7)$ & $13.30^{\mathrm{ij}}$ & $27.50 \mathrm{kl}$ & $10.75^{\mathrm{k}}$ & $5.25^{\mathrm{a}}$ & 10.00 def & $3.01^{\mathrm{jk}}$ & $1.26^{\mathrm{c}}$ & $3.03 \mathrm{de}$ & 1.57 ghij \\
\hline $\mathrm{P}(8)$ & $12.25^{\mathrm{ijkl}}$ & $25.50 \mathrm{mno}$ & $10.14^{\mathrm{lm}}$ & $0.88^{b}$ & 10.00 def & $2.72^{\mathrm{lm}}$ & $1.79 \mathrm{abc}$ & $2.91 \mathrm{de}$ & 1.63 ghij \\
\hline $\mathrm{P}(9)$ & $10.21^{\mathrm{i}}$ & $22.50^{q}$ & $8.45^{\circ}$ & $0.69^{b}$ & $7.00^{f}$ & $1.50^{\circ}$ & $1.11^{\mathrm{c}}$ & 1.59 ef & $0.77^{\mathrm{lm}}$ \\
\hline $\mathrm{P}(10)$ & $16.80^{\text {efg }}$ & $29.75^{\mathrm{ij}}$ & $11.70^{\mathrm{i}}$ & $0.96^{\mathrm{b}}$ & $14.00^{\mathrm{d}}$ & $3.38^{\mathrm{fg}}$ & $2.06^{a b c}$ & $3.33^{\text {cde }}$ & $2.15^{f}$ \\
\hline $\mathrm{P}(11)$ & $12.50 \mathrm{ijk}$ & $27.00 \mathrm{klm}$ & $12.00^{\mathrm{i}}$ & $1.06^{b}$ & $20.00^{b}$ & $3.06^{\mathrm{jk}}$ & $1.51 \mathrm{abc}$ & $2.17^{\text {def }}$ & $1.27^{\mathrm{jk}}$ \\
\hline $\mathrm{P}(12)$ & $11.30^{\mathrm{jkl}}$ & $25.00^{\text {no }}$ & $10.42^{\mathrm{kl}}$ & $0.89^{b}$ & $8.00^{\text {ef }}$ & $2.20^{n}$ & $1.89 \mathrm{abc}$ & $1.22^{\mathrm{f}}$ & $0.72^{\mathrm{lm}}$ \\
\hline $\mathrm{P}(13)$ & $16.00^{\text {fgh }}$ & $33.00 \mathrm{~g}$ & $12.80^{g}$ & $1.01^{\mathrm{b}}$ & $12.00 \mathrm{def}$ & $3.14^{\text {hijk }}$ & $2.26^{\mathrm{abc}}$ & 1.95 def & $1.30^{\mathrm{jk}}$ \\
\hline $\mathrm{P}(14)$ & $12.05^{\mathrm{ijkl}}$ & $26.50^{\mathrm{lmn}}$ & $11.20^{j}$ & $0.89^{b}$ & $7.00^{\mathrm{f}}$ & $2.94^{\mathrm{kl}}$ & $1.91 \mathrm{abc}$ & 2.33 def & $1.40^{\text {hijk }}$ \\
\hline $\mathrm{P}(15)$ & $15.40 \mathrm{gh}$ & $31.00^{\mathrm{hi}}$ & $12.20^{\mathrm{h}}$ & $1.09^{b}$ & $12.00 \mathrm{de}$ & 3.21 ghij & $2.31^{\mathrm{abc}}$ & $3.47^{\mathrm{cd}}$ & 1.78 fghi \\
\hline $\mathrm{P}(16)$ & $18.55^{\mathrm{e}}$ & $34.50^{\mathrm{f}}$ & $14.80 \mathrm{de}$ & $1.15^{\mathrm{b}}$ & $20.00^{b}$ & 3.30 ghi & $2.30 \mathrm{abc}$ & $3.52^{\mathrm{cd}}$ & $2.21^{\mathrm{fg}}$ \\
\hline $\mathrm{P}(17)$ & 16.70 efg & $32.50 \mathrm{gh}$ & $13.75^{f}$ & $1.04^{b}$ & 12.00 def & $3.37 \mathrm{gh}$ & $2.36^{\mathrm{abc}}$ & $3.11^{\mathrm{de}}$ & $1.87^{\text {fghi }}$ \\
\hline $\mathrm{P}(18)$ & $12.90^{\mathrm{ijk}}$ & $27.00 \mathrm{klm}$ & $11.80^{\mathrm{i}}$ & $1.13^{b}$ & $24.00^{\mathrm{ab}}$ & $3.06^{\mathrm{jk}}$ & $1.95 \mathrm{abc}$ & 1.95 def & $1.53^{\text {hijk }}$ \\
\hline $\mathrm{P}(19)$ & $15.85 \mathrm{fgh}$ & $32.00 \mathrm{gh}$ & $12.90^{\mathrm{g}}$ & $1.38^{\mathrm{b}}$ & 10.00 def & $3.11^{\mathrm{ijk}}$ & $2.01 \mathrm{abc}$ & 1.84 def & $1.45^{\mathrm{ijk}}$ \\
\hline $\mathrm{P}(20)$ & $18.25^{\text {ef }}$ & $33.00^{g}$ & $13.90^{f}$ & $1.26^{\mathrm{b}}$ & 12.00 def & $3.63^{f}$ & $2.67^{a b c}$ & $3.28^{\text {cde }}$ & $1.98^{\mathrm{fgh}}$ \\
\hline $\mathrm{P}(21)$ & $29.20^{b c}$ & $44.00^{\mathrm{cd}}$ & $18.80^{\mathrm{b}}$ & $1.17^{b}$ & $28.00^{a}$ & $5.12^{a b}$ & $3.16^{\mathrm{ab}}$ & $6.16^{\mathrm{b}}$ & $4.10^{\mathrm{cd}}$ \\
\hline $\mathrm{P}(22)$ & $26.70^{d}$ & $41.00^{\mathrm{e}}$ & $14.75^{\mathrm{e}}$ & $1.06^{\mathrm{b}}$ & 12.00 def & $4.25^{\mathrm{e}}$ & $2.26^{a b c}$ & $4.78^{b c}$ & $2.14^{\mathrm{fg}}$ \\
\hline $\mathrm{P}(23)$ & $28.40^{\mathrm{cd}}$ & $44.50^{\mathrm{cd}}$ & $15.15^{\mathrm{d}}$ & $1.10^{\mathrm{b}}$ & $14.00^{\mathrm{de}}$ & $4.11^{\mathrm{e}}$ & $2.42^{a b c}$ & $4.71^{b c}$ & $3.05^{e}$ \\
\hline $\mathrm{P}(24)$ & $28.85^{b c}$ & $45.00^{c}$ & $19.95^{\mathrm{a}}$ & $1.11^{\mathrm{b}}$ & $28.00^{a}$ & $4.59^{\mathrm{d}}$ & $3.05^{\mathrm{ab}}$ & $5.31^{b}$ & $3.58^{\mathrm{d}}$ \\
\hline $\mathrm{P}(25)$ & $35.30^{a}$ & $48.00^{b}$ & $17.25^{c}$ & $1.26^{\mathrm{b}}$ & $18.00^{\mathrm{bc}}$ & $5.05^{a b c}$ & $3.06^{\mathrm{ab}}$ & $5.77^{b}$ & $3.99^{c}$ \\
\hline $\mathrm{P}(26)$ & $30.95^{b}$ & $48.00^{\mathrm{b}}$ & $19.20^{\mathrm{b}}$ & $1.37^{b}$ & $20.00^{b}$ & $4.86^{\mathrm{bc}}$ & $3.21^{\mathrm{a}}$ & $8.12^{\mathrm{a}}$ & $5.18^{b}$ \\
\hline $\mathrm{P}(27)$ & $30.60^{b c}$ & $54.50^{\mathrm{a}}$ & $19.00^{\mathrm{b}}$ & $1.20^{\mathrm{b}}$ & $26.00^{a}$ & $5.17^{\mathrm{a}}$ & $3.25^{\mathrm{a}}$ & $8.45^{a}$ & $6.32^{a}$ \\
\hline $\mathrm{P}(28)$ & $31.35^{b}$ & $43.00^{\mathrm{d}}$ & $19.30^{\mathrm{b}}$ & $1.22^{b}$ & $28.00^{a}$ & $5.01 \mathrm{abc}$ & $3.14^{\mathrm{ab}}$ & $5.90^{\mathrm{b}}$ & $3.52^{d}$ \\
\hline $\mathrm{P}(29)$ & $28.90 \mathrm{bcd}$ & $45.00^{c}$ & 15.00 de & $1.11^{\mathrm{b}}$ & $18.00^{\mathrm{cd}}$ & $4.10^{\mathrm{e}}$ & $2.47 \mathrm{abc}$ & $4.74^{b c}$ & $3.00^{\mathrm{e}}$ \\
\hline $\mathrm{P}(30)$ & $29.10^{b c}$ & $45.00^{c}$ & $20.10^{a}$ & $1.45^{\mathrm{b}}$ & $28.00^{\mathrm{ab}}$ & $4.78^{\mathrm{cd}}$ & $2.90 \mathrm{abc}$ & $5.72^{b}$ & $4.24^{\mathrm{cd}}$ \\
\hline Critical Value & 1.726 & 1.434 & 0.345 & 1.295 & 4.152 & 0.19 & 0.187 & 0.282 & 0.346 \\
\hline $\mathrm{SE}(\mathrm{m})$ & 0.608 & 0.505 & 0.122 & 0.456 & 1.463 & 0.067 & 0.066 & 0.099 & 0.122 \\
\hline
\end{tabular}

Means followed by the same letter are not significantly different at $p=0.05$. DMRT $=$ Duncan's multiple range test $\mathrm{CD}(p \leq 0.05)=$ critical difference, $\mathrm{SE}(\mathrm{m})=$ standard error. $\mathrm{P}=$ plant populations from three sites (1-30) (plant populations of Colchicum luteum).

The mean intracluster and intracluster distances $\left(\mathrm{D}^{2}\right)$ values for the data revealed the highest intrinsic distance $\left(\mathrm{D}^{2}\right)$ (6.97640) of cluster-1, followed by cluster-5 of the cluster-5 (5.10289), with the highest interclusters $\left(D^{2}\right)(46.55588)$ in the cluster-5 and the subcluster 3 (41.61871) (Table 5), respectively, with the Cabsicum annuum L. [56]. Between clusters 1 and 3 , the maximum intercluster distance was found. Shayam [52] evaluated the 32 genotype features of the sunflower where the maximum interface between cluster- 6 and cluster- 7 was reported. The work assisted to identify the superior genotype among diverse genotypes. 
Table 5. Mean intra (diagonal) and inter (above diagonal) cluster distances $\left(\mathrm{D}^{2}\right)$ among 30 populations of Colchicum luteum of forest hills of Kashmir Himalaya.

\begin{tabular}{cccccc}
\hline Cluster No. & Cluster-1 & Cluster-2 & Cluster-3 & Cluster-4 & Cluster-5 \\
\hline Cluster 1 & 6.97640 & 32.83606 & 38.77118 & 23.74613 & 30.81826 \\
\hline Cluster 2 & - & 0.00000 & 41.61871 & 34.44198 & 37.65239 \\
\hline Cluster 3 & - & - & 0.582752 & 38.35003 & 46.55588 \\
\hline Cluster 4 & - & - & - & 3.32208 & 31.43609 \\
\hline Cluster 5 & - & - & - & - & 5.10289 \\
\hline
\end{tabular}

Among the clusters with more than one population, the maximum intracluster distance included high yielding populations. Selection of parents from different clusters having wider intercluster distance and also showing good intracluster diversity for a set of economic traits have been useful in creating broad genetic base segregants after this hybridization $[52,57,58]$. Cluster means for different characters help in choosing the diverse parents for an initiating hybridization program which will eventually broaden the genetic base of the species. Further, there are chances of obtaining transgressive segregants with high heterotic effects [43,59-62]. Sardana et al. (1997) observed that cluster means and genotypic variation reveal interesting pictures about the nature of diversity and having maximum opportunities crossing between genotypes of different clusters and are expected to give maximum heterosis

The DMRT has been performed using the "agricolae" package of $\mathrm{R}$ studio software version 3.6.3. In this method, all the possible differences between the means of the genotypes for various parameters under study have been calculated and are given in Table 4 .

\section{Conclusions}

This study highlighted the presence of considerable morphological variations in 30 populations of C. luteum collected from three different agro-climatic regions of Kashmir Himalaya. The majority of the populations were grouped in cluster-1, followed by cluster- 5 . The plant species possess sufficient genetic diversity among the populations. Cluster means of different characters help in choosing the diverse parents for hybridization. Keeping in view the ruthless overexploitation of endangered plant species, it is important to safeguard them. A hybridization program between identified diverse parents will help to broaden the genetic base and to identify the transgressive segregants with high heterotic segregants. Parent investigation has attempted to group the genotypes in different clusters which can serve as a base for the selection of parents. Cluster- 5 is a promising one for better yield and yield attributing traits. The present study concluded that plant species possessed sufficient genetic diversity among the 30 populations, 7 populations from cluster- 5 of the undisturbed area in Harwan, and consequently the populations from the same cluster can be multiplied for an initiating conservation and breeding program and can serve as a tool for the scientific community to evolve better contemporary varieties of $C$. luteum with profitable characters such as more yield of corms, etc. This will assist farmers, particularly the marginal farmers, to alleviate their income. Further studies are required to study the population's C. luteum extensively to devise a package for strengthening the conservation measures of this endangered plant species.

Author Contributions: R.A.R. and H.B. drafted the experimental design and R.A.R., M.A.B., H.B., S.A.P. and A.F. performed the statistical analysis. R.A.R. also performed the lab experimental analysis, and R.A.R., A.F., H.M.A., K.R.H., H.N., M.A.B. and S.A.P. helped in data collection, data analysis, and the initial draft of the manuscript text. All authors have read and agreed to the published version of the manuscript. 
Funding: This Project was funded by the Deanship of Scientific Research (DSR) at King Abdulaziz University, Jeddah, under grant No. DF-752-130-1441. The authors, therefore, acknowledge with thanks DSR for technical and financial support.

Institutional Review Board Statement: Not applicable.

Informed Consent Statement: Not applicable.

Data Availability Statement: Data sharing not applicable to this article.

Acknowledgments: This Project was funded by the Deanship of Scientific Research (DSR) at King Abdulaziz University, Jeddah, under grant No. DF-752-130-1441. The authors, therefore, acknowledge with thanks DSR for technical and financial support. The authors would like to acknowledge the Division of Environmental Sciences, FoH, SKUAST-K, J\&K, India, for help provided in carrying out this study.

Conflicts of Interest: All authors agree to submit this manuscript in this periodical. There is no conflict of interest among the authors or with any external agency.

\section{References}

1. Shinwari, Z.K.; Malik, S.; Karim, A.M.; Faisal, R.; Qaiser, M. Biological activities of commonly used medicinal plants from Ghazi Brotha, Attock district. Pak. J. Bot. 2015, 47, 113-120.

2. Wani, M.Y.; Ganie, N.A.; Rather, R.A.; Rani, S.; Bhat, Z.A. Seri biodiversity: An important approach for improving quality of life. J. Ent. Zool. Stud. 2018, 6, 100-105.

3. Yeshiwas, Y.; Tadele, E.; Tiruneh, W. The dynamics of medicinal plants utilization practice nexus its health and economic role in Ethiopia: A review paper. Int. J. Biodiv. Conserv. 2019, 11, 31-47.

4. Howland, O. Fakes and chemicals: Indigenous medicine in contemporary Kenya and implications for health equity. Int. J. Equity Health 2020, 19, 1-2. [CrossRef]

5. Kurnaz, M.L.; Kurnaz, I.A. Commercialization of medicinal bioeconomy resources and sustainability. Sust. Chem. Pharm. 2021, 22, 100484. [CrossRef]

6. Hamilton, A.C. Medicinal plants, conservation and livelihoods. Biodiv. Conserv. 2004, 13, 1477-1517. [CrossRef]

7. Balunas, M.J.; Kinghorn, A.D. Drug discovery from medicinal plants. Life Sci. 2005, 78, 431-441. [CrossRef]

8. Aftab, T.; Hakeem, K.R. Medicinal and Aromatic Plants: Healthcare and Industrial Applications; Springer Nature: Basingstoke, UK, 2021.

9. Rather, R.A.; Wani, A.W.; Mumtaz, S.; Padder, S.A.; Khan, A.H.; Almohana, A.I.; Almojil, S.F.; Alam, S.S.; Baba, T.R. Bioenergy Bioenergy: A foundation to environmental sustainability in a changing global climate scenario. J King Saud Univ. Sci. 2021, 34, 101734. [CrossRef]

10. Ross, I.A. Medicinal Plants of the World (Volume 3): Chemical Constituents, Traditional and Modern Medicinal Uses; Humana Press Inc.: Totowa, NJ, USA, 2005; pp. 110-132.

11. Malik, S.; Bano, H.; Rather, R.A.; Ahmad, S. Cloud seeding; Its prospects and concerns in the modern world-A review. Int. J. Pure Appl. Biosci. 2018, 6, 791-796. [CrossRef]

12. Edison, L.K.; Kumar, S.P.; Pradeep, N.S. Educating biodiversity. In Bioresources and Bioprocess in Biotechnology; Springer: Singapore, 2017; pp. 143-165.

13. Heywood, V.H.; Iriondo, J.M. Plant conservation: Old problems, new perspectives. Biol. Conserv. 2003, 113, 321-335. [CrossRef]

14. Zerabruk, S.; Yirga, G. Traditional knowledge of medicinal plants in Gindeberet district, Western Ethiopia. S. Afr. J. Bot. 2012, 78, 165-169. [CrossRef]

15. Ripple, W.J.; Abernethy, K.; Betts, M.G.; Chapron, G.; Dirzo, R.; Galetti, M.; Levi, T.; Lindsey, P.A.; Macdonald, D.W.; Machovina, B.; et al. Bushmeat hunting and extinction risk to the world's mammals. R. Soc. Open Sci. 2016, 3, 160498. [CrossRef] [PubMed]

16. Ma, S.; Khayatnezhad, M.; Minaeifar, A.A. Genetic diversity and relationships among Hypericum L. species by ISSR Markers: A high value medicinal plant from Northern of Iran. Caryologia 2021, 20, 97-107. [CrossRef]

17. Rasool, R.; Fayaz, A.; Ul Shafiq, M.; Singh, H.; Ahmed, P. Land use land cover change in Kashmir Himalaya: Linking remote sensing with an indicator based DPSIR approach. Ecol. Indic. 2021, 125, 07447. [CrossRef]

18. Shinwari, Z.K.; Gilani, S.S. Sustainable harvest of medicinal plants at Bulashbar Nullah, Astore (northern Pakistan). J. Ethnopharmacol. 2003, 84, 289-298. [CrossRef]

19. Ahmed, S.N.; Ahmad, M.; Shinwari, Z.K.; Shinwari, S. Taxonomic, pharmacognostic and physicochemical authentication of Colchicum luteum Baker (Suranjantalkh) from its commercial adulterant. Pak. J. Bot. 2016, 48, 2039.

20. Bhattachar, S.K. Hand Book of Medicinal Plants; Pointer Publishers: Jaipur, India, 1998; p. 110.

21. Dulloo, M.E.; Estrada Carmona, N.; Rana, J.C.; Yadav, R.; Grazioli, F. Varietal Threat Index for Monitoring Crop Diversity on Farms in Five Agro-Ecological Regions in India. Diversity 2021, 11, 514. [CrossRef] 
22. Bano, H.; Lone, F.A.; Bhat, J.I.; Rather, R.A.; Malik, S.; Bhat, M.A. Hokersar wet land of Kashmir: Its utility and factors responsible for its degradation. Plant Arch. 2018, 18, 1905-1910.

23. Goded, S.; Ekroos, J.; Azcárate, J.G.; Guitian, J.A.; Smith, H.G. Effects of organic farming on plant and butterfly functional diversity in mosaic landscapes. Agric. Ecosyst. Environ. 2019, 284, 106600. [CrossRef]

24. Franklin, C.M.; Harper, K.A.; Clarke, M.J. Trends in studies of edge influence on vegetation at human-created and natural forest edges across time and space. Can. J. For. Res. 2021, 51, 274-282. [CrossRef]

25. Capraro, H.G. In the Alkaloids; Brossi, A., Ed.; Academic Press: Cambridge, MA, USA, 1984; Volume 23, pp. 1-70.

26. Ondra, P.; Valka, I.; Vicar, J.; Sütlüpinar, N.; Simasnek, V. Chromatographic determination of constituents of the genus Colchicum (Liliaceae). J. Chromatogr. 1995, 704, 351-356. [CrossRef]

27. Karlik, E.; Deger, M.; Erdal, U.Z.; Gozukirmizi, N. Pioneering in vitro studies for callus formation of colchicum chalcedonicum azn. Trakya Univ. J. Nat. Sci. 2020, 21, 131-137.

28. Massarotti, A.; Coluccia, A.; Silvestri, R.; Sorba, G.; Brancale, A. The tubulin colchicine domain: A molecular modeling perspective. ChemMedChem 2012, 7, 33-42. [CrossRef] [PubMed]

29. Naaz, F.; Haider, M.R.; Shafi, S.; Yar, M.S. Anti-tubulin agents of natural origin: Targeting taxol, vinca, and colchicine binding domains. Eur. J. Med. Chem. 2019, 1, 310-331. [CrossRef] [PubMed]

30. Blakeslee, A.F.; Avery, A.G. Methods of inducing doubling of chromosomes in plants: By treatment with colchicine. J. Hered. 1937, 28, 393-411. [CrossRef]

31. Manzoor, A.; Ahmad, T.; Bashir, M.A.; Hafiz, I.A.; Silvestri, C. Studies on colchicine induced chromosome doubling for enhancement of quality traits in ornamental plants. Plants 2019, 8, 194. [CrossRef] [PubMed]

32. Fatima, B.; Usman, M.; Khan, M.S.; Khan, I.A.; Khan, M.M. Identification of citrus polyploids using chromosome counts, morphological and SSR markers. Pak. J. Agric. Sci. 2015, 52, 1.

33. Mehta, I.; Chaudhary, H.K.; Sharma, P.; Manoj, N.V.; Singh, K.; Sran, R.S. In vivo colchicine manipulation for enhancing DH production efficiency in Triticum durum using Imperata cylindrica-mediated chromosome elimination approach. Cereal Res. Commun. 2020, 48, 217-224. [CrossRef]

34. Wechsler, B. Colchicine and Behcet's disease: An efficacious treatment finally recognized! La Rev. De Med. Interne 2002, $23,3$.

35. Anzengruber, F.; Graf, V.; Hafner, J.; Meienberger, N.; Guenova, E.; Dummer, R. Efficacy and safety of colchicine in inflammatory skin diseases: A retrospective, monocentric study in a large tertiary center. J. Dermatol. Treat. 2021, 2, 104-109. [CrossRef]

36. Aisen, P.S.; Marin, D.B.; Brickman, A.M.; Santoro, J.; Fusco, M. Pilot tolerability studies of hydroxychloroquine and colchicine in Alzheimer disease. Alzheimer Dis. Assoc. Disord. 2001, 15, 96-101. [CrossRef] [PubMed]

37. Ahmad, B.; Khan, H.; Bashir, S.; Ali, M. Antimicrobial bioassay of Colchicum luteum Baker. J. Enzym. Inhib. Med. Chem. 2006, 21, 765-769. [CrossRef] [PubMed]

38. Yakoubi, R.; Megateli, S.; Sadok, T.H.; Gali, L. Photoprotective, antioxidant, anticholinesterase activities and phenolic contents of different Algerian Mentha pulegium extracts. Biocatal. Agric. Biotechnol. 2021, 34, 102038. [CrossRef]

39. Leonard, B.J.; Wilkinson, J.F. Desacetylmethylcolchicine in treatment of myeloid leukaemia. Br. Med. J. 1955, 1, 874. [CrossRef]

40. Yue, Q.X.; Liu, X.; Guo, D.A. Microtubule-binding natural products for cancer therapy. Planta Medica 2010, 76, 1037-1043. [CrossRef]

41. Toplan, G.G.; Gürer, C.; Afife, M. Importance of Colchicum species in modern therapy and its significance in Turkey. J. Pharm. Istanb. 2016, 46, 129-144.

42. Rao, C.R. Advanced Statistical Methods in Biometrical Research, 1st ed.; John Wiley and Sons: New York, NY, USA, 1952.

43. Rao, T.P.; Gomathinayagam, P. Genetic diversity in semi dry rice bunder different environments. Madras Agric. J. 1997, 84, 314-317.

44. Ahmad, T.; Borah, P. Genetic diversity in glutinous rice germplasm of Assam. Oryza 1999, 36, 74-75.

45. Hukumchand, P.S. Genetic diversity analysis for quantitative traits in advanced breeding lines of sesame (Sesamum indicum L.). Int. J. Curr. Microbiol. Appl. Sci. 2019, 8, 2970-2979.

46. Haralayya, D.; Salimath, P.M.; Aghora, T.S.; Adivappar, N.; Ganga, P.S. Genetic diversity analysis by D $^{2}$ clustering of yield and yield attributing traits in French bean (Phaseolus vulgaris L.). J. Pharmacogn. Phytochem. 2017, 6, 1331-1335.

47. Arunachalam, V. Genetic distance in plant. Ind. J. Genet. Plant Breed. 1981, 41, 226-236.

48. Bano, H.; Rather, R.A.; Bhat, J.I.A.; Bhat, T.T.; Azad, H.; Bhat, S.A.; Hamid, F.; Bhat, M.A. Effect of pre-sowing treatments using phytohormones and other dormancy breaking chemicals on seed germination of Dioscorea deltoidea Wall. Ex Griseb.: An Endangered Medicinal Plant Species of North Western Himalaya. Ecol. Environ. Conserv. 2021, 27, $253-260$.

49. Wani, M.Y.; Rather, R.A.; Bashir, M.; Shafi, S.; Rani, S. Effect of zinc on the larval growth and quality cocoon parameters of silkworm (Bombyx mori L.): A review. Int. J. Fauna Biol. Stud. 2018, 5, 31-36.

50. Wani, M.Y.; Mir, M.R.; Mehraj, S.; Rather, R.A.; Ganie, N.A.; Baqual, M.F.; Sahaf, K.A.; Hussain, A. Effect of different types of mulches on the germination and seedling growth of mulberry (Morus SP.). Int. J. Chem. Stud. 2018, 6, 1364.

51. Lakshman, S.S.; Chakraborty, N.R.; Debnath, S.; Kant, A. Genetic variability, character association and divergence studies in sunflower (Helianthus annuus L.) for improvement in oil yield. Afr. J. Biol. Sci. 2021, 3, 129-145. [CrossRef]

52. Shyam, C.; Chandrakar, P.K.; Rastogi, N.K.; Banjare, U. Evaluation of Genetic Divergence Analysis in Wheat for Yield and its Component Characters. Int. J. Agric. Environ. Biotechnol. 2018, 11, 829-834. [CrossRef] 
53. Hazra, P.; Sahu, P.K.; Roy, U.; Dutta, R.; Roy, T.; Chattopadhyay, A. Heterosis in relation to multivariate genetic divergence in brinjal (Solanum melongena). Ind. J. Agric. Sci. 2010, 80, 119-124.

54. Kumar, S.; Rattan, P.; Sharma, J.P.; Gupta, R.K. D ${ }^{2}$ analysis for fruit yield and quality components in tomato (Lycopersicon esculentum Mill.). Ind. J. Plant Gen. Res. 2010, 23, 318-320.

55. Padder, S.A.; Mansoor, S.; Bhat, S.A.; Baba, T.R.; Rather, R.A.; Wani, S.M.; Popescu, S.M.; Sofi, S.; Aziz, M.A.; Hefft, D.I.; et al. Bacterial endophyte community dynamics in apple (Malus domestica Borkh.) germplasm and their evaluation for scab management strategies. J. Fungi 2021, 7, 923. [CrossRef]

56. Rahevar, P.M.; Patel, J.N.; Axatjoshi, S.; Gediya, L.N. Genetic diversity study in chilli (Capsicum annuum L.) using multivariate approaches. Electr. J. Plant Breed. 2021, 12, 314-324.

57. Singh, A.K.; Singh, S.B.; Singh, S.M. Genetic divergence in scented and fine genotypes of rice (Oryza sativa L.). Ann. Agric. Res. 1996, 17, 163-166.

58. Wani, M.Y.; Mehraj, S.; Rather, R.A.; Rani, S.; Hajam, O.A.; Ganie, N.A.; Mir, M.R.; Baqual, M.F.; Kamili, A.S. Systemic acquired resistance (SAR): A novel strategy for plant protection with reference to mulberry. Int. J. Chem. Stud. 2018, 2, 1184-1192.

59. Qian, Y.W.; He, K.M. Utilization of exotic rice germlasm resources in Guang-dong province. Crop. Genet. Resour. $1991,2,36-37$.

60. Ibrahim, A.U.; Yadav, B.; Anusha, R.; Magashi, A.I. Heterosis studies in durum wheat (Triticum durum L.). J. Genet. Genom. Plant Breed. 2020, 4, 2-8.

61. Rather, R.A.; Bano, H.; Padder, S.A.; Perveen, K.; Al Masoudi LM Alam, S.S.; Hong, S.H. Anthropogenic Impacts on Phytosociological Features and Soil Microbial Health of Colchicum luteum L. An Endangered Medicinal Plant of North Western Himalaya. Saudi J. Biol. Sci. 2022, 10. [CrossRef]

62. Sardana, S.; Borthakur, D.N.; Lakhanpal, T.N. Genetic divergence in rice germplasm of Tripura. Oryza 1997, 34, $201-208$. 